\title{
Multidimensional phenomena of Hajj: study of Javanese pilgrims
}

\author{
M. Zulfa \\ Institut Agama Islam Negeri Salatiga \\ E-mail:mzulfa76@yahoo.com
}

\begin{abstract}
Performing Hajj pilgrimage to Mecca is the fifth pillar of Islam, whereas these five pillars of Islam are believed by all Muslims in the world as the foundation of Islam. Hajj is a must for any Muslim who has all the abilities, in term of financial, physical, as well as psychological, to perform it, This paper is a report of a research on various aspects accompanying the accomplishment of the Hajj pilgrimage to Mecca by the pilgrims. Those aspects are the spiritualteologic, the psychological, the sociological, and the economic. The objects of the research were the city of Salatiga, the District of Semarang, and the District of Magelang. The spiritual-teologic aspect is used to explain the level of religiousity of a Muslim performing the Hajj while the psychological aspect is related to the psycho-condition, mental, and desires experienced or possessed by the pilgrims. The sociological aspect is the social faithfulness, the social harmony supported by those pilgrims. Last but not least, the economic aspect is the motive of the pilgrims to increase their prosperity or their economic power. By implementing the descriptive-qualitative approach, this research aimed at providing objective, accurate, and systematic depictions of those issues related with the objects of the research. For the data collection, the researcher used various methods such as observation, interview, and documentation. The data was then analyzed through the descriptive qualitativequantitative approach. The result shows that the spiritual-teologic, the psy-
\end{abstract}


chological, the sociological, as well as the economic aspects are all present in the accomplishment of the Hajj, with the spiritual-teologic and the psychological aspects play the most dominant roles. The quantitative analysis shows that there is a significant influence of the spiritual-teologic and the psychological aspects toward the completion of the Hajj of the pilgrims. It is proven with the statistical calculation that the degree of significant is $1 \%$ and $5 \%$ that shows that the $r$ sum is bigger than the $r$ table or that $0,599>0,345>$ 0,266. Meanwhile, the descriptive analysis of the data shows that the spiritual-teologic and the psychological aspects are the more dominant aspects compared to the sociological, as well as the economic aspects.

Haji merupakan rukun Islam yang ke lima, sementara rukun Islam dijadikan sebagai pondasi dasar agama oleh seluruh umat Islam di dunia. Setiap muslim yang telah mampu, hukumnya wajib menunaikan ibadah haji. Baik mampu secara financial maupun mampu secara fisik ataupun psikis. Tulisan ini merupakan hasil penelitian yang menfokluskan beberapa aspek yang menyertai jama'ah haji. Aspek-aspek itu meliputi: aspek teologis-spiritual, aspek psikologis, aspek sosiologis dan yang terakhir aspek ekonomis dengan mengambil objek penelitian di Kota Salatiga, Kab. Semarang dan Kab. magelang. Aspek teologisspiritual adalah aspek yang menjelaskan mengenai tingkat religiusitas seseorang secara individu ketika melaksanakan ibadah haji, sedangkan aspek psikologis yaitu, aspek yang berhubungan dengan psikis, mental, keinginan-keinginan dialami yang dirasakan oleh jama'ah haji. Selanjutnya aspek sosiologis, merupakan kesalehan sosial, hubungan kemasyarakatan yang dilakukan oleh jama'ah haji. Dan yang terakhir aspek ekonomis, yaitu motif jama'ah dalam melakukan ibadah haji adakah faktor atau keinginan meningkatkan ekonomi. Dengan menggunakan pendekatan deskriptif-kuantitatif penelitian ini bertujuan untuk mendapatkan gambaran yang objektif, akurat dan sistematis, mengenai masalah-masalah yang ada di objek penelitian. Untuk mengumpulkan data digunakan beberapa metode yaitu, observasi, interview dan dokumentasi. Kemudian data yang telah terkumpul dianalisis menggunakan pendekatan deskriptif kualitatif-kuantitatif. Hasil penelitian menunjukkan bahwa aspek teologis-spiritual, aspek psikologis, aspek sosiologis dan aspek ekonomis menyertai para jamaah haji terutama aspek spiritual dan psikologis. Dari analisis secara kuantitatif menunjukkan adanya pengaruh signifikan aspek teologis-spiritual dan aspek psikologis terhadap jama'ah haji. Hal itu dibuktikan dengan 
hasil perhitungan statistik pada taraf signifikansi 1\% dan 5\% menunjukkan bahwa $r$ hitung lebih besar dari $r$ tabel yaitu: 0,599>0,345>0,266. Sedangkan analisis deskriptif menghasilkan bahwa aspek teologis-spiritual dan aspek psikologis adalah aspek yang lebih menonjol jika dibandingkan dengan aspek aspek-aspek lainnya, dibanding aspek sosiologis dan aspek ekonomis.

Keywords: Hajj; Phenomenology; Javanese; Pilgrims

\section{Introduction}

Religious services, or known as religious rituals, are believed to be the very important element of any religion, ${ }^{1}$ so is the meaning of Hajj as part of Islamic rituals for Muslims. This is why in performing the Hajj, the process is started by the proclamation of the talbiyah, the declared intention to fulfill or to attend to Allah's invitation.

As a form of ritual, Hajj provides a very deep and profound message to Muslim as this ritual is believed to eventually upgrade Muslim status, in respect to the dedication paid to the religious service and to the social status of the Hajj accomplishers claiming the honorific call as a Hajj.

To reach the level of Haji Mabrur is the ultimate goal of any Muslim performing the Hajj as they expect that the Eden will be their reward in the hereafter. This predication of haji mabrur is always kept in mind of those Hajj pilgrims. Therefore, in performing the Hajj ritual, every pilgrim does their best to include all influential aspects of their spiritual and social lives (Hablun min Allah wa hablun min al-nass) in all process of the Hajj either in Mecca or in Medina, in the hope that the reach the level of the haji mabrur. By the inclusion of the spiritual and social activities in performing the Hajj ritual, a Hajj pilgrim trully believes that the predication of haji mabrur is achievable. Similarly important, a Hajj pilgrim needs

${ }^{1}$ Nurcholish Madjid, Islam, Doktrin dan Peradaban, Jakarta: Yayasan Wakaf Paramadina, 1992, 57. 
to stay away from any misdeeds or misbehaviours that prevent him or her accomplish the heavenly rewards for performing the Hajj. Popular terms related to this inelligibility in deserving the heavenly rewards are the fusuq (mischiefs), rafats (porn) dan jidal (dispute). It is said in the AlQur'an Sura Al-Baqarah verse 197:

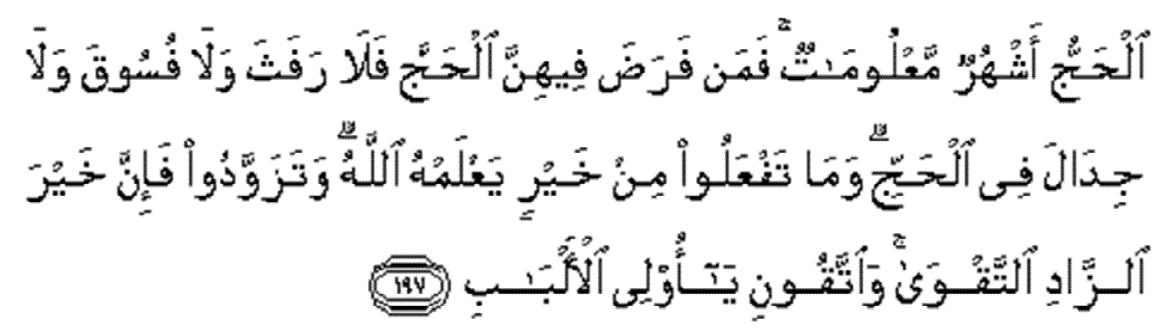

"The Hajj (pilgrimage) is (in) the well-known (lunar year) months (i.e. the 10th month, the 11th month and the first ten days of the 12th month of the Islamic calendar, i.e. two months and ten days). So whosoever intends to perform Hajj therein by assuming Ihram), then he should not have sexual relations (with his wife), nor commit sin, nor dispute unjustly during the Hajj. And whatever good you do, (be sure) Allah knows it. And take a provision (with you) for the journey, but the best provision is At-Taqwa (piety, righteousness, etc.). So fear Me, O men of understanding!"2

Due to the profound understanding of the fusuq, rafats dan jidal shared by the prospective performers of the Hajj, many of them who are actually ready in term of physical as well as financial condition to perform the ritual, they postpone it due to their being doubtful about their situations in regard to the fusuq, rafats and jidal. They feel that they are not spiritually well prepared for the Hajj ritual.

\footnotetext{
${ }^{2}$ Interpretation of the meaning of the Noble Quran published by Dar-us-Salam Publication, http://www.noblequran.com/translation/
} 
To what extent is the pilgrims' implementation of the spiritual and the social values in their avoidances of the acts categorized as fusuq, rafats and jidal is very interesting to research upon. The spiritual value discussed here is the 'spirit' of the religious activities or the psychological condition created or driven by the faith and devotion to Allah. This 'soul' or 'spirit' of religiousity influences greatly the pilgrims' attitudes and behaviours. Thus, the solemnity and the spiritual in-depth of the Hajj pilgrims create the mentality of the pilgrims to stay away from any immoral and forbidden acts prescribed by Islamic Law. It is strongly assumed that these spiritual values prevent the performers of the Hajj from commiting negative acts categorized as fusuq, rafats and jidal. The real condition in performing the Hajj pilgrimage is indeed not an easy test for the pilgrims to stay away from those negative acts, especially those of jidal because of the over crowded pilgrims, while each of them needs to feel pleasant and feel iritated when others obstruct their way. It can happen that pilgrims involve in some arguments and brawls among them due to their personal intention to have comfortable place and solemnity to accomplish their Hajj rituals though all of them know that everyone needs to do pretty much similar thing in the process of the Hajj rituals. This competition to find the comfortable place and solemnity provoke the pilgrim to involve in a dispute or jidal that may end up in a fight or even a brawl among them. Places where the pilgrims may commit jidal are everywhere and sometime unanticipated, those places can even be in the hometown or the homecountry of the pilgrims, or in Mecca and also Medina or even in places on their way back after the Hajj pilgrimage.

\section{Hajj as the highpoint of the five Islamic pillars}

Hajj as one of the five pillars of Islam is the high point of the pillars or te fifth and the final pillars. The Prophet Muhammad SAW once said this 
very popular remark "...there will be no reward for haji mabrur, but the Eden." In other words it is the Eden that can be the most proper reward for those pilgrims deserving the predicate of haji mabrur. That Hadist is indeed very welknown and always become great motivation for prospective Hajj performers and also those who have not had chance and ability to perform Hajj. This is one of the reason why from year to year the number of Muslims in Indonesia planing to go for the Hajj pilgrimage increases significantly though the expenses spent for performing the Hajj keeps increasing also. This financial matters seems not to lower the intentions of Muslims in Indonesia to set their mind to register themselves to go to Mecca for the Hajj pilgrimage. Due to the lure of achieving the predicate of "haji mabrur" of which the reward is the Eden, the applicants for the trip of Hajj is booming in recent years thus the quota of the Hajj pilgrims as it is allocated by the Kingdom of Saudi of Arabia to the government of Indonesia annualy can no longer be sufficient to accomodate all the applicants. This is indeed the only cause of the existing 'waiting list' that requires the prospective Hajj performers need to queue for more than seven years from the time they are officially listed as potential applicants (after fulfilling all the administration and financial requirements) to finally get the seats at the flight to Arab Saudi for the Hajj. This is the uniqueness of the Hajj rituals compared to other rituals listed in the five pillars of Islam and this makes Hajj the high point of the five pillars.

The Eden as the guaranted reward for the Hajj pilgrims deserving the predicate of haji mabrur is truly special because this predicate of mabrur is not entitled to other pillars of Islam but the Hajj. The Eden as the guaranted reward for the Hajj pilgrims invokes such great power for Moslims eventhough the requirement to be entitled as mabrur is indeed so hard to fulfill. This predicate or title of mabrur is very closely related to either vertical or horisontal dimensions of the ritual or the hablun min 
Allah wa hablun min al nâs (while the interaction of any Muslim to Allah gets better through any rituals they perform thus the interaction with fellow human being will get better also). In this sense, the al hajju al mabrur (pilgrim deserving the title mabrur) is expected to show unbreakable faith and devoutness to (hablun min Allah) and at the same time do all good deeds to others. Simply saying, in the concept of al hajju al mabrur, there are two dimensions, first is the dimention of faith, and second is the dimension of good deeds (amal saleh). These two dimensions in the process of Hajj will be detailed in the spiritual-theological, psychological, sociological, and also economical perspectives, in the next paragraphs of this paper.

Afterwards the writer will also elaborate some values or aspects connected with the concept of hablun min Allah dan hablun min al nās which shall always accompany the Hajj pilgrimage. Those values will also be seen in the spiritual-theological, psychological, sociological, and also economical perspectives.

\section{The Hajj ritual and its spiritual-theological aspect}

In the discourse of Islamic studies, human is a creature of two dimensions, the spiritual and the physical dimensions. Human body consists of materials in need of other materials that sometimes acquired through ways of evil or misdeeds. While the spiritual dimension or the soul of human is immaterial and needs spiritual fulfillment that tends to leads human being to divinity. In Islam, all form of rituals; Sholat (prayers), Fast, Zakat (Devine tax) and Hajj provide kind of exercises for human soul to get closer in its interaction to Allah SWT. In performing the Hajj pilgrimage, all efforts to purify human soul are done in the form of training the soul through all steps in the Hajj ritual procedure starting from Wukuf in Arafah, throwing Jumrah (stones) in Mina, then Thawaf and 
Sa'i. It has become Muslims' knowledge that every pilgrim accomplishing all the Hajj ritual procedure feels what so called spiritual closeness while they perform rituals next to Ka'bah. The Hajj pilgrim feels that s/ he involves in a dialogue with Allah, as if they stand before Allah as they truly believe that Ka'bah is the House of Allah (Baitullah). Hence whenever they perform their prayers next to Ka'bah and in its surrounding, they feel that they do that before Allah SWT.

Islam gives various solutions to human to reach the highest degree of spirituality and spiritual peacefulness. One of the solutions is to perform various Islamic rituals and among the many kinds of rituals, Hajj ritual achieves its own high point and is significant in the forging of human soul. In many discourse in Islamic studies, it is said that Hajj is the completion of Islamic Jurisprudence, is the flag of Islam, in addition to its being one of the five pillars of Islam ${ }^{3}$

For all Hajj pilgrims, all ritual activities included in the procedure of performing the Hajj or the manasik at the Holy land Mecca and Medina have become the biggest and the worthiest spiritual experiences as they feel that they have met and seen the presence of Allah in the limit of their consciousness while they are at the Holy lands. ${ }^{4}$

\section{The Hajj ritual and its psychologic aspect}

Various objectives listed below are the indicators of psychologic aspect accompanying the Hajj pilgrims: To renew spirit of life; To acquire spiritual values that create peacefulness; To attain spiritual satisfaction in life; To behold with their own eyes Ka'bah as the kiblat salat or the focal direction that all Muslims in the world face their head to; To see for them-

\footnotetext{
${ }^{3}$ http://indonesian.irib.ir/momentum, 5desember 2013.

${ }^{4}$ Ghufron Ajib Masadi, Haji Menangkap Makna Fisikal dan Spiritual, Jakarta: Raja Grafindo Persada, 1998, 39.
} 
selves the existence of the grand Mosque Masjidil Haram; To know all information regarding Hajj pilgrimage to Mecca; To go for recreation at the Holy lands but at the same time perform ritual of the final pillar of the five Islamic Pillars.

It has been explained previously that the spiritual-theologic aspect has dominated the attitudes and behaviours of the pilgrims and the psychologic aspect certainly accompanies the pilgrims in accomplishing the Hajj ritual. The psychologic aspect is actually intermingled with the spiritualtheologic aspect. The difference is that the spiritual-theologic aspect emphasizes the mental condition created by the solemnity of the rituals while the psychologic aspect related to mental condition that reacts to the worldly life like for example the belief that after the completion of the Hajj ritual, the pilgrim will earn lots more prosperity that what they used to earn before. They expect that they will also gain new spirit and better work ethic upon finishing the Hajj ritual compare to their condition before going for the Hajj pilgrimage.

For the Hajj pilgrims, all activities at the holy lands become inner experiences, great and worthiest psychologic happening that soothe their mental and soul, as though they have become one with their Lord, Allah. This conscience is hoped to remain in their possesion and become great spirit to live future life after the accomplishment of the Hajj. ${ }^{5}$

In performing the Religious Hajj pilgrimage, not all pilgirms will gain similar inner experiences, though it can be said that all of them agree that accomplishing the Hajj gives them some very memorable and lovely experiences in their life. Hajj in a way provoke the feeling of longing for being back at the holy lands whenever they have opportunities to do so eventhough it means that they need to spend big money to satisfy their

\footnotetext{
${ }^{5}$ Ajib, Ghufron, Mas'adi, Haji Menangkap Makna..., 39.
} 
longing for the Hajj experiences. This is indeed the thing so called as the invaluable psychologic experience resulted from the accomplishment of Hajj ritual.

\section{The Hajj ritual and its sociological aspect}

The Hajj pilgrimage to Mecca was first initiated by the Prophet Ibrahim a.s. in about 3600 years ago. After the era of Ibrahim, the practices of the Hajj pilgrimage to Mecca has undergone lots of modifications but then Muhammad saw brought the practices back to what they were intended in time of Ibrahim. One of the practices that was amended by the Prophet Muhammad saw was the activity that was against the values of humanism. The proof for this amendment was the Prophet Muhammad's sermon that specifically address isues of humanity. In his sermon after performing his Wada or last Hajj, the Prophet emphasized on values of humanity such as (a) egalitarianism; (b) the obligation to protect other people's soul, property, and honour; and (c) the prohibition to commit any oppression or exploitation to the needy people either economically or in any other ways. ${ }^{6}$

Among so many lessons learnt from accomplishing the Hajj is the awareness to promote ukhuwah insaniyah (the brotherhood of humanity). This is why the Holy Qur'an addresses the believers in the verse of Hajj not as the "believers" but as "human" emphasizing that through performing Hajj, Muslims are invited to return to their existence as human that will enable them to maintain universal brotherhood of humanity. ${ }^{7}$

\footnotetext{
${ }^{6}$ Quraish Shihab, Membumikan Al-Qur'an, Jakarta: Mizan, 1992, 334.

${ }^{7}$ Nurcholish Madjid, Islam Doktrin dan Peradaban, Jakarta: Yayasan Wakaf Paramadina, 1992, xviii.
} 
Indeed, in performing Hajj, values of humanity can be felt not when the pilgrims are contemplating in their still positions but when they move in harmony. In this sense, brotherhood of humanity shall not be seen as something static but dynamic, thus acquiring the predicate of haji mabrur necessitates the pilgrims to promote social solidarity.

The sosiologic aspect of Hajj is generally colored by the spirit of cooperation and willingness to prioritize values of humanity that are manifested in attitudes as indicated below: Enthusiasm/cherfulness on the coordinated trip to Saudi Arabia; Feeling of togetherness in various moments; Spirit of doing things cooperatively; Spirit to help others; Engaged in active communication to ther pilgrims; Enthusiasm in social rituals; Spirit to share or donate for philantrophy.

In the journey for the Hajj pilgrimage organized by the government of Indonesia, the mood of togetherness, cooperation and helping each others is carefully plan and premeditated through the establishment of flight groups and sub groups of the flight groups. This coordinating system to share works and responsibilities is executed even when the pilgrims are still in their hometowns.

In that groupings since pre-departure, the feeling of togetherness and joyfulness persists. The nuance of brotherhood and good interaction among the members of the groups have been developed since the predeparture time. Things all members of the groups can discuss are among others their daily meals while staying at the hotel, whether they will cook by themselves or pay a food catering services with all expenses related to heir daily needs shared among themselves. This also promote the feeling of togetherness and joyfulness among themselves that will last till the end of the Hajj or even long after they are back again in their hometowns through regular group reunions through activities organized by 
their locally established Hajj brotherhood.

Regardless of the shared feeling of togetherness and cooperation among members of the flight group for the Hajj journey, sometimes conflict among them arises due to trivial matters though will not prevail or get ven more serious that provoke rivalries or hostile intentions to one another.

What becomes more important is the fact that the feeling of togetherness, cooperation, brotherhood, willingness to collect funds for philanthrophy and social goodness and ritual keep occuring and prevails long after they arrive back in their hometown through activities organized monthly by their locally established Hajj brotherhood to increase and maintain their personal and social piousness embodied in the concept of hablun min Allah wa hablun min al nas.

\section{The Hajj ritual and its economical aspect}

The enthusiasm as it is described in Sura (surat) Ibrahim verse 37, as Allah answers the prays of the Prophet Ibrahim, has become the greatest motivativation for Muslims to perform Hajj pilgrimage:

"Our Lord! Lo! I have settled some of my posterity in an uncultivable valley near unto Thy holy House, our Lord! that they may establish proper worship; so incline some hearts of men that they may yearn toward them, and provide Thou them with fruits in order that they may be thankful". ${ }^{8}$

That verse serves as a trigger for the creation of a very powerful economy of the world with billions US dollars circulated in the season of Hajj "the biggest Islamic event" organized and celebrated by Muslim all over the world. In term of macroeconomics, the Hajj ritual has empow-

${ }^{8}$ The Holy Qur'an (Koran) English Translation of the Meanings by Muhammad Marmadukke and Pickthal..., 113. 
ered economics and financial potentials of the world to facilitate this biggest international conference all over the world held annually. In term of regional and microeconomics, the Hajj has driven Muslims in Indonesia to do their best to collect sufficient money to fulfill the invitation of Allah to perform this fifth pillar of Islam, the Hajj. How powerful this economic aspect is in the organization of the Hajj pilgrimage that there will never be any event in this world that can compete with the Hajj in term of the complication of the organization of the event, not to mention that the Hajj needs to be held annually without any hindrances. The successful management of the Hajj pilgrimage means a success in economy and also a success in the world's extraordinary communication and coordination. Hajj has given unprecedented economic impacts for individual pilgrim also starting from the financial planning, saving money consistently and discipline, controlling daily and monthly expenses for ensuring extra money for the Hajj saving. Also, the chance to meet with people from all over the world while performing Hajj has opened opportunities for international business communication for local, regional, national, or even international business scale. This economic networking has been set up and institutionalized either pre, while, or post organization of the Hajj season, only words of "subhanallah" may be sufficient to express this amazing Hajj complex organization.

Once a Muslim intends to perform Hajj pilgrimage to Mecca, s/he starts to collect and accumulate her or his economic potential, through saving more money, working harder to ensure increase in the income in one hand and control expenses in the other hand. All these efforts are orchestrated to achieve one ultimate goal, to realize their dream of going to Mecca for the Hajj.

Bussiness, saving, and prays are all directed for the fulfillment of the intention to perform Hajj pilgrimage to Mecca. What so special about 
the economic aspect of the Hajj is that all pilgrim are also tied to traditions to buy for the people close to them in relation, either neighbours, colleagues, or relatives, gifts of Hajj and this tradition of course necessitate additional big expenses. Also in Javanese traditions, a Hajj pilgrims needs to organize kind of pre-departure gathering called as "walimatu al safar", by inviting colleagues, neighbours, and relatives to come to a congregation specifically addressing various about Hajj pilgrimage to Mecca and in fulfilling the invitation they make ways to come and bring some donations to contribute to this good intention of the Hajj pilgrim. Thus, the economic aspect of the Hajj always deserves special attention as it is in itself fenomenal because of the the inclusion of not only funds for the expenses of performing the Hajj pilgrimage to Mecca but also funds spent on additional necessities explained above either pre, while, or post Hajj accomplishment. One important to note also is that though it is never spoken, but it is always the hope of all Hajj pilgrims that their economic power increase significantly after accomplishing Hajj. This hope has indeed turned into belief for most of the pilgrims no matter what actually happen with their life after performing the Hajj. This is the evidence that the economic aspect has been the inseparable part of the Hajj ritual and is truly included in all Indonesian pilgrims plan and preparation for the Hajj.

\section{Values in performing the Hajj ritual}

In performing Hajj, there are four important accompanying aspects, i.e spiritual-theologic, psychologic, sociologic, and economic. Each of those four aspects consists of key values described below:

\section{Spiritual-theological aspects}

The spiritual-theologic aspect in Hajj is indeed very significant as it becomes a strong fortification for the pilgrims to stay away from any prohibi- 
tion during the Hajj. This spiritual-theologic aspect is about the religious activities of the pilgrims that create certain state of devoutness driven by the spirit of faith and godliness to Allah SWT. This religious spirit finally influences the pilgrims' attitudes and behaviours. This religious spirit then invokes solemnity and profundity in performing all activities in the Hajj ritual. For doing so, the pilgrims strive to avoid misdeeds and all negative attitudes and behaviours that decrease the rewards of performing Hajj. In this spiritual-theologic aspect, there are values of spiritual such as:

Firstly, intention to perform the last/fifth pillar of Islam: Performing the Hajj for no other intentions but to fulfill an invitation from Allah SWT, thus the pilgrims complete and accomplish the last/fifth pillar of which is Hajj. This is reported as the first drive shared by Muslims in performing the Hajj pilgrimage to Mecca, which is to attend to the invitation of Allah to come to Mecca for the Hajj as prescribed to be the last five pillars of Islam.

Secondly, hope to have their sins forgiven: Muslims go the Mecca for the Hajj pilgrimage because they wish that their sins can be forgiven, with the realization that their being human makes them compliant to sins and forgetfulness. A Muslim will certainly feel calmer and relief wishing that their sins can be forgiven when s/he feels kind of closeness to Allah by, for instance, going for a pilgrimage to Holy land of Mecca. Mecca is believed to be the place of the Baitullah or the House of Allah, so automatically they feel kind of closeness to Allah when they are able to visit the Baitullah. All pilgrims believe also that through their prayers and asking for forgiveness of all their sins while they are performing the Hajj, Allah will certainly forgive their sins, especially when they are able to perform the prayers in the efficacious places (mustajab). 
Thirdly, a wish to gain the ultimate reward/the Eden: For Muslims, their highest objective in their devoutness to Allah is to be permitted by Allah to live in the Eden in the life hereafter. The goal of Muslims in performing the Hajj is indeed the wish to gain the ultimate reward from Allah, the guarantee to enter the Eden or the Paradise. It has become the strong belief of most pilgrims.

Fourthly, a desire to experience religious rituals in the holy lands: Mecca is believed by Muslims to be the Baitullah or the House Allah. Performing religious rituals in the Baitullah will be given multiplied reward by Allah SWT. One of the goals for Muslims to go for the Hajj pilgrimage to Mecca is to to see with their own eyes the Ka'bah, the one and only direction where all Muslims all over the world turn in while performing their five daily prayers. Almost all pilgrims convey that as long as they arrive in Mecca, they are impatient to behold Masjidil Haram and Ka'bah.

Fifthly, a need to visit some historical places connected to the struggles of the Messengers of Allah and their true companions. "to kill two birds with one stoned" can become the proper saying that represent the need of the pilgrims to go to Mecca to perform Hajj and at the same time to have religious vacation by visiting historical places as the evidences of the start and the glory of the Islamic civilization.

Sixthly, a need to pray and solemn the heart while performing religious rituals: Mecca is believed by Muslims to be a sacred place that necessitate them to control their deeds and their words. While in Mecca, all prays uttered will be answered in one condition that the one uttering the pray is doing it sincerely, seriously, and abstaining from any prohibited acts prescribed by Islam. As the belief that Mecca is the efficacius place for prays to be answered, many relatives, friends, neighbours of the pilgrims ask them favours to also pray for their wishes hoping that their 
wishes can also be granted by Allah SWT eventhough they have not had opportunities to pray in Mecca themselves.

Seventhly, a necessity to absorb spiritual information: Beside the main reason to perform rituals for Allah, Muslims are motivated to perform Hajj because they want to gain religious or spiritual information. There is indeed this minor motive of some pilgrims to really experience spirituality for instance to get insights from Allah as solutions from their latent problems, or even to experience spiritual unique phenomenon or miraculous happenings to strengthen their spirituality.

Lastly, a wish to accomplish the predicate of haji mabrur: It has been great expectations or wishes of the pilgrims all religious rituals they performed during Hajj will be accepted and then granted the predicate of haji mabrur or that Allah SWT guarantees that their Hajj accomplishment has given and will always give positive impacts or spiritual development in their lives to come.

It is important to note that the value attached to any Muslim accomplishing the Hajj can be seen from the degree of the manifestation of the predicate haji mabrur through answering the following questions ${ }^{9}$ : Whether the intention is good or bad like for example the intention to perform the Hajj is merely to show faithfulness to Allah, or the intention is to show off (riya'/ sum'ah) or for any other worldly sake such as politics; Whether all procedures in performing the Hajj have been perfectly accomplished or not; Whether the pilgrim is able or not to stay away or avoid things that are prohibited for them to do, especially those prohibitions in saying bad, or dirty, or porn words (rafats), prohibitions in commiting misdeeds (fasik/maksiat) and prohibition to involve in quarrel

\footnotetext{
${ }^{9}$ Masyfuk Zuhdi, Masail Fiqhiyah: Kapita Selekta Hukum Islam, Jakarta: PT Toko Gunung Agung, 2002, 288.
} 
or disputes (jidal), as this is prescribed in Sura al-Baqarah verse 197. "(The Hajj (pilgrimage) is (in) the well-known (lunar year) months (i.e. the 10th month, the 11th month and the first ten days of the 12th month of the Islamic calendar, i.e. two months and ten days). So whosoever intends to perform Hajj therein by assuming Ihram), then he should not have sexual relations (with his wife), nor commit sin, nor dispute unjustly during the Hajj. And whatever good you do, (be sure) Allah knows it. And take a provision (with you) for the journey, but the best provision is At-Taqwa (piety, righteousness, etc.). So fear Me, O men of understanding!)". ${ }^{10}$

And whether the pilgrim performs more or less additional rituals recommended while performing the Hajj i.e taking a bath, performing two series or rakaat of prescribed prayers, reciting takbir and tahlil on seeing the Ka'bah, saying talbiyah and others.

\section{Psychological aspect}

Besides the spiritual-theologic aspect, all Hajj pilgrims have to ensure preparedness in terms of mental, physic, and psychologic. In case of the psychologic aspect, the elements of preparedness are:

Firstly, the intention to gain new spirit in life. The main intention for a Muslim to perform the Hajj is indeed to fulfill the invitation from Allah to go to His Baitullah in Mecca but additionally Muslims also seek for new spirit in their lives, it means that their lives after the accomplishment of the Hajj will hopefully turn to be more meaningful, blessed, full of enthusiasm, and Allah blesses their every steps of their everyday lives.

Secondly, the intention to absorb soothing spiritual values. While Muslims perform the Hajj, their heart and soul will be in calm and peaceful condition. That leads to solemnity in performing all rituals or in

\footnotetext{
${ }^{10}$ Interpretation of the meaning of the Noble Quran published by Dar-us-Salam Publication, http://www.noblequran.com/translation/
} 
Javanese word, they feel kind of easiness or "entheng", in saying their prays to Allah they will also feel the devoutness.

Thirdly, the intention to have mental satisfaction in life. For Muslims, this mental satisfaction can only happen after fulfilling the invitation of Allah to go to Mecca for the Hajj pilgrimage. Having performed the Hajj provokes a feeling that one's life is complete and more perfect. This feeling creates some changes in attitudes of the pilgrims and tends to encourage the pilgirms to intensify and multiply their religious devoutness and activities.

Fourthly, the intention to behold the Ka'bah as the direction of all Muslims all over the world turn in while performing their sholat or prayers. It is not suprising that Muslims need to see Ka'bah with their very eyes as $K a ' b a h$ is the only direction that all Muslims turn in while performing their five daily prayers. This intention is shared by all of the Hajj pilgrims though some of them may have had seen it before in their previous Hajj or Umroh. This intention indeed affects the degree of mental satisfaction and extraordinary happiness of the pilgrims thus very often the pilgrims burst into tears when they first see the $K a^{\prime} b a h$ or at least feel that deepest touched on their heart.

Fifthly, the intention to behold Masjidil Haram. Masjidil haram is a historic mosque in the islamic civilization as it is one of the oldest established mosques all over the world. It also becomes an evidence, a symbol of Muslims in their fight for upholding values and teaching of Islam, The beauty of this mosque is even more visible at night. Thousand lamps illuminating the mosque and it is a very interesting view for all to pilgrims to behold. It is not surprising then that all the pilgrims feel curious and want to behold Masjidil Haram with their very eyes.

Sixthly, the intention to gain information on rituals of religious pilgrimage. 
Information on rituals of religious pilgrimage will expand their knowledge on various things such as how to do wukuf, ihram, sa'i (little run from the Safa hill to Marwa hill) and the historical backgrounds of all activities performed in the process of the Hajj.

Lastly, the intention to go for vacation to the holy lands Mecca and Medina and at the same time accomplish the last pillar of Islam, the Hajj.

Some of the pilgrims feel kind of a lost while they have done the Hajj pilgrimage but have not spent times enjoying the beauty of the holy lands Mecca and Medina and other holy lands in Arab Saudi.

\section{Sociological Aspect}

While performing the Hajj, the pilgrims cannot stay away from the interaction to other fellow pilgrims and also other pilgrims from various countries of the world staying at the same dormitory maktab. In that interaction, the pilgrims do their best to help each other, share things, make donations, etc. From the research it can be known that the pilgrims list these following social phenomena accompanying the accomplishement of the Hajj:

Firstly, shared enthusiasm and joyfulness during the journey to the Hajj pilgrimage. The journey for the Hajj is felt as a short journey since the pilgrims spent the time of the journey enthusiastically and joyfully. This phenomenon may indeed provoke some of those pilgrims who have just come back from their journey plan to go for another journey of the Hajj the following so they immediately reapply for seat arrangement for the next season of the Hajj.

Secondly, spirit of togetherness in various kind of interactions The spirit of togetherness felt when involved in various kind of interactions make the pilgrims happy because they will get to know each other better 
and eventually strengthen the brotherhood among Muslims. This spirit of togetherness and brotherhood are present in the pilgrims' everyday lives while performing the Hajj.

Thirdly, the Spirit of cooperation. There is an adagium in Bahasa Indonesia "berat sama dipikul ringan sama dijinjing" or "to evenly share burden and responsibilities among friends". This principle as prescribed in the adagium has become a convention among the pilgrims whenever they involve in interactions while performing the Hajj. Pilgrims promote cooperation among themselves in any possible ways, including when they prepare their daily meals and when they anticipate and solve problems. For instance, when a pilgrim announced that s/he had lost his/her money, other pilgrims immediately donate their money to ease the sadness and reduce the consequences of having less money to spend. Any kinds of problem then will be perceived as solvable with that spirit of cooperation. All pilgrims are happy in promoting cooperation among them. This phenomenon last longer as even after the pilgrims are back at their hometown, they constitute a group of silaturrahim or good companionship, that allows members to get together every month to involve in good activities such as Islamic conggregation.

Fourthly, the spirit to help those in needs. All pilgrims believe that helping others while performing the Hajj will serve also as a form of ritual that will be granted big reward by Allah SWT. This spirit to give a helping hand is motivated by a belief that all good deeds will come back to the doers and either will bad deeds. This spirit prevails till after the pilgrims get bak to their hometown especially when they constitutes the Hajj unions or brotherhood. The Hajj union or brotherhood generally launch social programs for helping the needy, fakir miskin, yatim piatu and provide scholarships for bright students with limited financial supports from their families. 
Fifthly, the spirit to communicate with other pilgrims. It is off course easier for a pilgrim to communicate with other pilgrims when s/he can speak various languages and conversely a pilgrim will find it very difficult to communicate with other pilgrims when s/he cannot apprehend the language used by the partner in communication. The case can be different when the pilgrims are facilitated by tour guide, this will reduce or even eliminate problem with their communication with other pilgrim speaking other languages. Communication with other pilgrims speaking other language while at the holy lands is kind of inevitable. Those pilgrims who are not really capable of speaking the language of the counterparts and the counterparts cannot understand Bahasa Indonesia, will necessarily use sign languages or body languages in order for the communication to happen.

Sixthly, the spirit to perform social rituals. All pilgrims will be enthusiastic to perform social rituals as there are two things involved in this kind of rituals that are the Hablun min Allah wa hablun min al nas (the interaction of Muslims with Allah and the interaction of Muslims with other human being) and this enthusiasm can be seen not only when the pilgrims perform the Hajj ritual but also when they have been back to their hometowns. They will establish union of the Hajj or brotherhood of the Hajj which is in local context of Indonesia popularly known as IPHI (Ikatan Persaudaraan Haji Indonesia or an Association of Indonesian Hajj Broterhood).

Lastly, the spirit to donate alms. The pilgrims posses high spirit to donate during the accomplishement of the Hajj, indeed most of them have brought with them extra money for the donation as alms. They absolutely believe that to donate as alms while performing Hajj will be granted by Allah with multiplied rewards. However, this spirit to donate as alms will not come to an end after the pilgrims go back to their home- 
towns. They initiate various social programs, such as bulding halls for homebase of the local association of Hajj brotherhood (IPHI) and other social gathering such as congregation, wedding ceremony, etc., establishing schools, medical clinic or even hospital. This is the proves that the accomplishment of Hajj brings some very positive impacts that common people actually feel and take benefit of.

\section{Economical aspect}

What is meant by economical aspect here is the capability of the Pilgrims to realize the intention to go for the Hajj pilgrimage to Mecca. Lots of money need to be saved to register for a seat in the government management of Hajj, it reaches to an approximate 37 to 38 millions rupiah in the last couple of years. The money saved by the potential Hajj pilgrims must be sufficient for the minimum expense as prescribed by the government for the transportation, accommodation, and administration and still the pilgrims need to also save enough money for the expense while they are at the holy lands to cover other expenses not prescribed by the government, last but not least extra more money need to be prepared also to fulfill the daily needs of their family left at home. In addition to those expenses, some pilgrims also prepare and save lots more money to make new business or expand their long established business as they believe that their accomplishment of the Hajj will widely open the possibility to recieve Allah's blessing and to accept lots more increases in their financial power. Not only that, some pilgrims also expect that by the time they get back from performing the Hajj, they can initiate some business transaction with new business partners they met during the Hajj. In general, in economical aspect, the notable elements involved are described as:

Firstly, the efforts to save money in discipline to pay for the Hajj related expenses. Performing the Hajj pilgrimage to Mecca is the top goal 
of life of all Muslims all over the world as Islam prescribes that it is a must for Muslim with the ability to perform the Hajj as the last or the fifth pillar of Islam. This is why a Muslim needs to save certain amount of money only for the accomplishment of the Hajj pilgrimage to Mecca.

Secondly, prudent in spending. What is meant by prudent in spending in this research is to spend one's income in accordance with the real need of that person, not his or her desire to spend. In addition to popular advice to donate money as alms when a Muslim really intends to earn lots more income, a Muslim as also adviced not to spend income on things $\mathrm{s} /$ he desires but to spend only on things they really need or in the Javanese local wisdom it is known as ambeg parama arta. To abide this principle, a Javanese Muslim even has to neglect his or her own desire in order to have the extra money to spend on gifts really necessary to present to friends, neighbours, and relatives soon they are back from the Hajj pilgrimage. For buying gifts, a Javanese Muslim may necessarily be prudent in spending for their own sake so that his or her intention to perform social rituals, to share gifts with friends, neighbours, and relatives can be realized.

Thirdly, attitudes to business in Hajj. Attitudes to business in Hajj as reported in this research is to address an issue that sometimes, a Hajj pilgrims has other intentions than the main intention to perform the Hajj pilgrimage to Mecca like for instance the intention to do or to develop business while performing the Hajj. Though it very rarely happens done by the registered pilgrims, it is sometimes done by those pilgrims who also serve as facilitator for the group of pilgrims as delegated by the government or in Indonesian context they are called as PBIH. They also do some business such as selling phone credits or become brokers for various goods or gifts that the pilgrims need.

Thirdly, the thought to start various businesses after coming back from the Hajj. Coming back from the Hajj, a Muslim certainly has lots more 
relations and new acquaintances. This what makes a Muslim who has just gone back from the Hajj develops a though to start his or her new business. It is found in this research that a Muslim who used to sell logs, developed a tought to start business in selling furniture after meeting with other fellow pilgrims who happen to be businessman in selling furniture also. It can happen with any of the pilgrims after coming back from the Hajj pilgrimage to Mecca. Communication as well as ties of friendship (silaturrahmi) among the Hajj indeed facilitates them to establish networking of business. This is in line with the pray which literary means "always profitable trades" or in Arabic known as wa tijäratan lan tabür.

Fourthly, the prays/wishes that after the Hajj comes good fortunes or ever increasing livelihood. Good fortunes is the expectation of all people. The pilgrims share this expectation also. Pilgrims really hope that after performing the Hajj, their livelihood will keep get better. This is the thing that almost all pilgrims dare to admit.

Fifthly, the planned business relationship among the pilgrims. Though it is not the thing that all pilgrims experience during the Hajj, those pilgrims whose profesions related to trade and entrepreneurship, use all oppurtunities available, while in the holy lands also, to do business with other fellow pilgrims. This is done to establish business relationship or expand their already established business. This is one thing called as the other effect of communication between the pilgrims. They are economically benefited from their Hajj rituals.

Sixthly, the conscience of their intention to go for the Hajj pilgrimage to Mecca makes great impact to their economic condition. Many Muslims hold on to the conscience that one's intention to go for the Hajj pilgrimage to Mecca makes great impact to his or her economic condition. Accomplishing Hajj gives very positive impacts to the pilgrims in one condition that the pilgrims are seen by Allah as truly sincere and faithful. 
Allah then will ease and speed up the fulfillment of their wishes and one of the many ways is to hasten their good fortunes. This belief is based on the words of Allah in Sura At Thalaq verse 2 and 3: “...and whosoever keepeth his duty to Allah, Allah will appoint a way out for him. and will provide for him from [a quarter] whence he hath no expectation. ..."

\section{Conclusion}

Through the analysis of the data on aspects accompanying the accomplishment of the Hajj as they are experienced and felt by the pilgrims, it can be concluded that: Firstly, spiritual-Theologic aspects accompanying the accomplishment of the Hajj in category A (extremely felt) is reported by as many as $70,9 \%$ of the Hajj pilgrims, while categori B (adequately felt) is reported by $20 \%$ of the pilgrims. It shows that the spiritual-theologic aspect is reported to be experienced and felt by $90,90 \%$ of the pilgrims. This data also reveals that the degree of religiousity as well as spirituality of the pilgrims are in the level of the very high enthusiasm, or that more than $90 \%$ of the pilgrims are truly motivated by the force to accomplish the fifth or the last of five pillars of Islam, to have all their sins forgiven by Allah, to gain ultimate reward from Allah which is the Eden or Paradise, to behold $\mathrm{Ka}$ 'bah as the only direction for performing five daily prayers and any additional prayers, as well as to reach the level of solemnity for the heart whenever prayers are spoken.

Secondly, the psychologic aspect in category A (extremely felt) is reported by as many as $49,09 \%$ of the pilgrims, while for categori $\mathrm{B}$ (adeguately felt) the number reaches to $30,91 \%$. This shows that in total $80 \%$ of the pilgrims experienced and felt the psychologic aspect accompanying their Hajj ritual. The psychologic aspect invoke the pilgrims to

11 The Holy Qur'an (Koran) English Translation of the Meanings by Muhammad Marmadukke and Pickthal..., 1. 
gain new spirit of life, to have mental peacefulness and mental satisfaction in living their lives.

Thirdly, the sociologic aspect experienced and felt by the pilgrims while performing the Hajj ritual, for category A (extremely felt) reaches the percentage of $63,64 \%$, while for category $B$ (adeguately felt) reaches the percentage of $18,18 \%$ of all the pilgrims. It means that $81,82 \%$ of the pilgrims reported that the psychologic aspect accompanying their Hajj rituals is experienced and felt at the level of extreme and adeguate. This also shows that many pilgrims developed enthusiasm and joyfulness during the Hajj accomplishment. They also promoted the spirit of cooperation and togetherness and also giving a helping hand to one another while performing the Hajj.

Last but not least, economical aspect does not really influence the pilgrims since the data shows only $23,64 \%$ in category A (extremely felt) and $14,55 \%$ in category B (adeguately felt). It means that merely 38,19\% of the pilgrim reported that they experienced and felt this economic aspect accompanying their Hajj rituals. This become the evidence that pilgrims spent few times thinking economic matters especially those related to business and networking while at the holy lands.

Considering all the aforementioned data analysis, it can be concluded that the spiritual-theologic aspect and the psychologic aspect play the more dominant role in influencing the attitudes and behaviours of the pilgrims, then followed by the social and economic aspect.

Finally, this brief revelation on the Hajj phenomenon in the perspective of spiritual-theologic, psychologic, social, and economic accompanying the Hajj ritual is completed in the hope that every reader may take all advantages in reading this research paper. 
IJIMS, Indonesian Journal of Islam and Muslim Societies, Volume 5, Number 1, June 2015: 135-162

\section{Bibliography}

Ajib, Ghufron, Mas'adi. Haji, Menangkap Makna Fisikal dan Spiritual. Jakarta: Grafindo Persada, 1998.

Kerajaan Arab Saudi, 1999, Al-Qur'an danTerjemahannya, Khadim Al Haramain. Madjid, Nurkholish. Islam Doktrin danPeradaban. Jakarta: YayasanWakaf Paramadina,1992.

Madjid, Nurcholish. Perjalanan Religius Umrah dan Haji. Jakarta: Yayasan Wakaf Paramadina, 1997.

Shihab, M. Quraish. Membumikan al-Qur'an. Bandung: Mizan,1992. http://indonesian.irib.ir/momentum, 5 Desember 2013.

Masjfuk, Zuhdi. Masail Fiqhiyah: Kapita Selekta Hukum Islam. Jakarta: PT Toko Gunung Agung, 2002. 